\title{
Deletion of the H19 transcription unit reveals the existence of a putative imprinting control element
}

\author{
Marie-Anne Ripoche, ${ }^{1}$ Chantal Kress, ${ }^{2}$ Françoise Poirier, ${ }^{1}$ and Luisa Dandolo ${ }^{1,3}$ \\ ${ }^{1}$ Institut Cochin de Génétique Moléculaire (ICGM) Institut National de la Santé et de la Recherche Médicale (INSERM) \\ U257, Paris 75014, France; ${ }^{2}$ Biologie du Développement, Institut Pasteur, Paris 75015, France
}

\begin{abstract}
The distal region of mouse chromosome 7 contains a cluster of imprinted genes that includes $\mathrm{H} 19$ and Igf2 (insulin-like growth factor 2). H19 is expressed as an untranslated RNA found at high levels in endodermal and mesodermal embryonic tissues. This gene is imprinted and exclusively expressed from the allele of maternal origin. The Igf2 gene shows a similar pattern of expression but is expressed from the paternal allele. We have generated a targeted deletion of the $\mathrm{H19}$ transcription unit by insertion of a neo replacement cassette. The homozygous mutant animals are viable and fertile and display an overgrowth phenotype of $8 \%$ compared with wild-type littermates. This is associated with the disruption of Igf 2 imprinting and the consequent biallelic expression of this gene. A striking feature of the recombinant $\mathrm{H19}$ allele is the occurrence of a parental imprint set on the neo replacement cassette. Therefore imprinting of the H19 locus is independent of the $\mathrm{H19}$ gene itself. Taken together with the results of a larger $\mathrm{H19}$ mutation described previously, this indicates that an imprinting control element is located within the region $10 \mathrm{~kb}$ upstream of H19.
\end{abstract}

[Key Words: H19; homologous recombination; Igf2; genomic imprinting]

Received January 16, 1997; revised version accepted April 24, 1997.

In mammals, normal embryonic development is achieved only in the presence of the maternal and paternal genome (McGrath and Solter 1984; Surani et al. 1984). Extensive research using mice carrying translocations has shown that certain chromosomal regions must carry genes for which the maternal and paternal copy are not functionally identical (Cattanach and Kirk 1985; Beechey and Cattanach 1996). This observation has led to the notion of an imprint set on certain genes during gametogenesis. This results in differential expression of the two parental alleles of these genes, which can occur at certain developmental stages and in certain tissues. Imprinting can therefore be defined by two steps: marking of certain genes at the time the two genomes are separated and recognition of this marking at specific times during embryogenesis. The mechanism by which imprinting is established is as yet unknown, although methylation of $\mathrm{CpGs}$ is a possible candidate ( $\mathrm{Li}$ et al. 1993; Razin and Cedar 1994). Whether this methylation is a cause or only a consequence of imprinting remains unclear (Sasaki et al. 1995).

To date, 17 genes have been shown to be imprinted in mouse and in man (for review, see Barlow 1995; John and Surani 1996). In the distal region of mouse chromosome 7 , a cluster of such genes covering $\sim 600 \mathrm{~kb}$ has been

${ }^{3}$ Corresponding author.

E-MAIL dandolo@cochin.inserm.fr; FAX 33-1-44-41-24-62. described. These genes are H19, Mash2, and $p 57^{\text {Kip2 }}$ (Bartolomei et al. 1991; Guillemot et al. 1995; Hatada and Mukai 1995), which are expressed from the chromosome of maternal origin, and Igf2 (insulin-like growth factor 2), and Ins2 (insulin 2), expressed from the chromosome of paternal origin (DeChiara et al. 1991; Giddings et al. 1994; Deltour et al. 1995) (see Fig. 1A). This imprint has also been identified on the human homologs of these genes (Zhang and Tycko 1992; Giannoukakis et al. 1993; Ohlsson et al. 1993; Matsuoka et al. 1996). A remarkable feature of this region is the reciprocal imprint set on the H19 and Igf2 genes, one being expressed from the maternal allele and the other from the paternal allele, over a distance of only $80 \mathrm{~kb}$, and their similar pattern of expression in many tissues during embryogenesis (Bartolomei et al. 1991; Zemel et al. 1992).

The $H 19$ gene is expressed at a very high level in endodermal and mesodermal tissues of the developing mouse embryo (Poirier et al. 1991). After birth, this expression is maintained during several days but then disappears in most tissues with the exception of adult muscle. The $2.5-\mathrm{kb}$ H19 RNA is spliced and polyadenylated but does not seem to encode a protein (Pachnis et al. 1988; Brannan et al. 1990). Although it has been suggested that $H 19$ could play a role as a tumor suppressor gene (Hao et al. 1993), no precise function has yet been assigned to this gene, which may play a role through a functional RNA. 
A
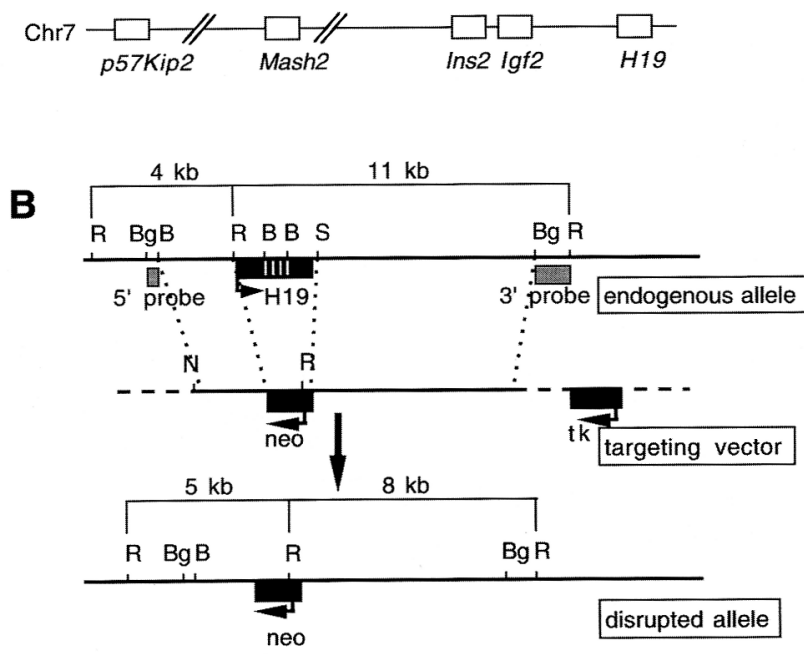

C
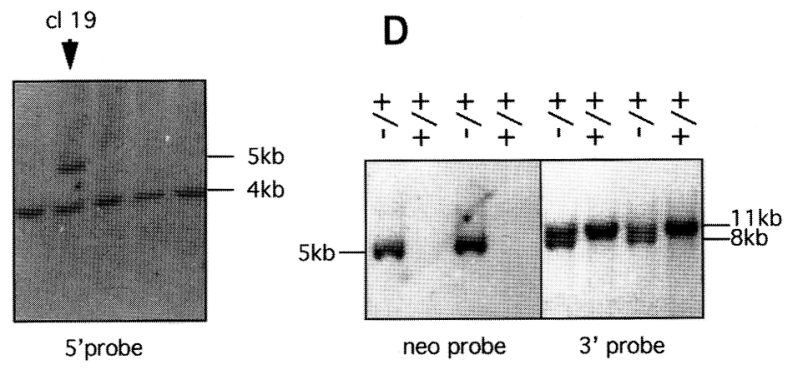

Figure 1. Targeted disruption of the $H 19$ gene. $(A)$ Position of the imprinted genes in the $600-\mathrm{kb}$ cluster on mouse chromosome 7. Igf2 and Ins2 are at a distance of 80 and $95 \mathrm{~kb}$, respectively; Mash2 at $230 \mathrm{~kb}$, and $p 57^{K I P 2}$ at $\sim 600 \mathrm{~kb}$ upstream from H19 (John and Surani 1996). (B) Restriction map of the genomic H19 region, the targeting vector, and the predicted structure of the disrupted allele. The coding regions are depicted by black boxes. The dashed line represents plasmid sequences. The EcoRI-Sall genomic fragment deleted in the targeting vector extends from $-50 \mathrm{bp}$ to $+3 \mathrm{~kb}$ relative to the start of transcription. The transcriptional direction of the H19, neo, and $t k$ genes is indicated by arrows. The neo and $t k$ transcripts are under the control of the pMC1 promoter $(P y$ virus enhancer and $t k$ promoter). The $5^{\prime}$ and $3^{\prime}$ external probes (gray boxes) were used to identify the recombinant alleles following EcoRI digestion of genomic DNA. (R) EcoRI; (B) BamHI; (Bg) BgIII; (S) SalI; (N) NotI. (C) Southern analysis of ES clones. Genomic DNA was digested with EcoRI and hybridized with the 5' external probe. The sizes of the endogenous $(4-\mathrm{kb})$ and disrupted $(5-\mathrm{kb})$ allele fragments are shown. The arrow shows ES clone 19, which is heterozygous and was used in blastocyst microinjections. $(D)$ Southern analysis of tail DNA from $F_{1}$ animals. Genomic DNA was digested with EcoRI and hybridized with a neo probe that detects a $5-\mathrm{kb}$ fragment, and with the 3 ' external probe that detects $11-\mathrm{kb}$ endogenous and $8-\mathrm{kb}$ mutated fragments. $1+1-1$ Heterozygous; $1+1+1$ wild-type animals.

The generation of mice carrying a null mutation of this gene can elucidate its role and possibly give further insight into the mechanism of imprinting. Mice carrying a $13-\mathrm{kb}$ deletion encompassing both the $\mathrm{H} 19$ gene and its upstream sequences have been described previously
(Leighton et al. 1995a). These mice are viable and fertile and show an increase in weight that is linked to biallelic expression of Igf2. We have created mice harboring a smaller deletion covering only the transcription unit of the gene. We report here that this 3-kb deletion also affects the growth of the mutant animals, although to a lesser extent, and that in contrast with the previous work, the neomycin resistance gene (neo) cassette that has been inserted at the H19 locus is imprinted. This implies that the signals required for the imprint are maintained in these mutant mice and that the H19 gene itself or its RNA product is not involved in the imprint of this locus. Given the difference between the two deletions, we also propose that a putative imprinting control element is located in the region $10 \mathrm{~kb}$ upstream of the $H 19$ gene.

\section{Results}

\section{Targeted disruption of the $\mathrm{H} 19$ gene}

The replacement construct that has been used to create a null mutation of the $\mathrm{H} 19$ gene by homologous recombination harbors a $3-\mathrm{kb}$ deletion of the entire transcription unit between the 5' EcoRI site and the 3' SalI site of the genomic DNA. All five exons of the gene are deleted, as well as an Spl site and the TATA box in the promoter region of $H 19$. The vector contains a 2-kb fragment of $5^{\prime}$ homology and a $6.5-\mathrm{kb}$ fragment of $3^{\prime}$ homology. The expected homologous recombinant allele results in a 3 -kb deletion replaced by the $1.1-\mathrm{kb}$ neo cassette. Both the neo and the herpes simplex virus thymidine kinase $(t k)$ cassettes are under the control of the $\mathrm{pMCl}$ promoter, composed of a Polyoma $(P y)$ enhancer (allowing expression in ES cells) and a tk promoter; contain a poly(A) addition signal; and are inserted in opposite orientation with respect to the $H 19$ transcription direction (Fig. 1B).

After electroporation of the CK35 ES cell line, 4 out of 60 clones displayed a correctly targeted allele as determined by Southern analysis (Fig. 1C). The $5^{\prime}$ external probe revealed a $5-\mathrm{kb}$ fragment from the mutant allele and a 4-kb fragment from the wild-type allele in EcoRIdigested genomic DNA from these clones. The 3' external probe revealed $8-\mathrm{kb}$ and $11-\mathrm{kb} E c o \mathrm{RI}$ fragments from the mutant and wild-type alleles, respectively (data not shown).

One clone ( $\mathrm{cl} 19$ ) was injected into blastocysts and the resulting male chimeras were mated with MF1 or C57BL/ 6 females to produce heterozygous $\mathrm{F}_{1}$ animals. These animals were tested for the presence of the neo gene by PCR on rapid-tail DNA preparations (as described in Materials and Methods). EcoRI-digested DNA was also analyzed by Southern blot using $5^{\prime}$ (data not shown), 3', and neo probes (Fig. 1D), showing the expected size fragments. Only one copy of the neo gene was detected in these animals, indicating a single insertion site of the targeting construct. These results confirm the presence of a correctly targeted allele, with the entire $3-\mathrm{kb}$ transcription unit of the $\mathrm{H} 19$ gene being replaced by the neo cassette. 


\section{Paternal and maternal transmission of the mutation}

The $H 19$ gene is imprinted and expressed only from the maternal allele. Therefore heterozygous $F_{1}$ offspring will display two phenotypes: (1) Mice in which the null allele is paternally inherited will carry a wild-type $H 19$ allele on the maternal chromosome that is normally expressed: These animals, called paternal heterozygotes (pat het), should display a wild-type phenotype; and (2) maternal heterozygotes (mat het), in which the null allele is maternally inherited, carry the wild-type $H 19$ allele on the paternal chromosome that is not expressed: mat het should display the same phenotype as homozygous mutants. This nomenclature was proposed previously for the Igf2 heterozygous mutants (DeChiara et al. 1990).

The heterozygous offspring from the male chimeras inherit the mutated allele paternally, and these pat het mice were identical to wild-type mice. In the $\mathrm{F}_{2}$ offspring from these mice, we found that pat het, mat het, and homozygous animals were all viable and fertile. The only observed phenotype was an increase in weight of the mat het and homozygous animals compared with their wild-type littermates. The increase ranged between $4 \%$ and $12 \%$ with a mean of $8 \%$, estimated on 100 animals (5-day neonates) from 12 litters. Mice from different backgrounds were analyzed and all displayed the same significant increase, as estimated by Student's $t$ test $(P<0.01)$. This weight difference was also maintained in adult animals (Table 1; Fig. 2).

Northern analysis on muscle and liver RNA from 5-day neonates showed expression of H19 in pat het mice. No $H 19$ transcript was detected in mat het (Fig. $3 \mathrm{~A}, \mathrm{~B})$ and in homozygous mutants (data not shown). This result confirms that the $H 19$ targeted allele is correctly mutated and that the imprint is maintained on the normal allele because the paternal $H 19$ allele is not expressed in mat het animals.

\section{Expression of the neo gene}

The same Northern blots were hybridized with a neo probe: neo transcripts were detected in mat het but not in pat het animals, which carry the neo gene on the paternally transmitted allele (Fig. 3C,D). These results show that the neo cassette that has been inserted at the H19 locus is subject to imprinting. The mutation that was introduced into these animals has therefore left intact the signals necessary for this imprint.

RNAs from adult tissues of mat het animals (kidney, liver, muscle, testis, and thymus) were hybridized with a neo probe (Fig. 4); expression of neo was detected only in muscle, therefore suggesting that the neo gene is under the same spatio-temporal regulation as the $H 19$ gene it has replaced.

\section{DNA methylation analysis of the $5^{\prime}$ upstream region}

It has been shown previously that the $5^{\prime}$ upstream region of the H19 gene is differentially methylated on the maternal and paternal allele (Bartolomei et al. 1993; Tremblay et al. 1995). To analyze the methylation profile of this region in the H19 mat het and pat het mice, genomic DNA from neonatal liver was digested with $E c o$ RI or with EcoRI and HpaII and hybridized to the $5^{\prime}$ external BgIII-BamHI probe (Fig. 5A,B). Double digestion of wildtype DNA shows a fully methylated 4-kb fragment (paternal allele) and several HpaII fragments (maternal allele). In mat het and pat het DNA samples, 4-kb (wildtype allele) and 5-kb (targeted allele) EcoRI fragments are detected. In mat het DNA, the 4-kb paternal fragment was resistant to HpaII digestion, indicating that the HpaII sites were methylated on the paternal allele, whereas the $5-\mathrm{kb}$ maternal fragment was sensitive to HpaII. Similarly, in pat het DNA samples, the $5-\mathrm{kb}$ paternal fragment was resistant to HpaII digestion (the ob-

Table 1. Weight of mutant animals

\begin{tabular}{|c|c|c|c|c|}
\hline Background & $\begin{array}{l}5 \text { day neonates } \\
\text { (litter no.) }\end{array}$ & \multicolumn{2}{|c|}{ Genotypes } & Percent \\
\hline \multirow{6}{*}{$\mathrm{MF} 1 / 129 \times \mathrm{C} 57$} & & mat het & wild type & \\
\hline & 1 & $2.16 \pm 0.03(n=3)$ & $1.98 \pm 0.04(n=7)$ & 8 \\
\hline & 2 & $3.92 \pm 0.07(n=4)$ & $3.63 \pm 0.07(n=6)$ & 7.4 \\
\hline & 3 & $4.61 \pm 0.07(n=6)$ & $4.42 \pm 0.09(n=4)$ & 4 \\
\hline & 4 and 5 & $3.97 \pm 0.10(n=7)$ & $3.48 \pm 0.12(n=9)$ & 12 \\
\hline & 6 & $3.74 \pm 0.12\langle n=5\}$ & $3.46 \pm 0.04(n=5)$ & 7.4 \\
\hline \multirow[t]{2}{*}{$\mathrm{C} 57 / 129 \times \mathrm{C} 57$} & 7 & $3.57 \pm 0.11(n=4)$ & $3.15 \pm 0.05(n=2)$ & 11.8 \\
\hline & 8 & $3.73 \pm 0.08(n=3)$ & $3.46 \pm 0.08(n=3)$ & 7 \\
\hline \multirow[t]{2}{*}{$\mathrm{C} 57 / 129 \times 129$} & 9 & $3.65 \pm 0.05(n=4)$ & $3.36 \pm 0.08(n=3)$ & 7.7 \\
\hline & & homozygotes & wild type & \\
\hline \multirow[t]{2}{*}{ C57/129 } & 10 & $4.86 \pm 0.06(n=3)$ & $4.28 \pm 0.15(n=5)$ & 12 \\
\hline & $11+12$ & $\begin{array}{c}\text { pat het } \\
2.90 \pm 0.16(n=5)\end{array}$ & $\begin{array}{c}\text { wild type } \\
3.0 \pm 0.11(n=11)\end{array}$ & -3 \\
\hline \multirow{3}{*}{$\mathrm{C} 57 / 129 \times 129$} & adults & mat het & wild type & \\
\hline & females & $28.2 \pm 1.3(n=8)$ & $25.1 \pm 1.2(n=6)$ & 11 \\
\hline & males & $24.2 \pm 2.0(n=2)$ & $22.2 \pm 0.9(n=6)$ & 8 \\
\hline
\end{tabular}




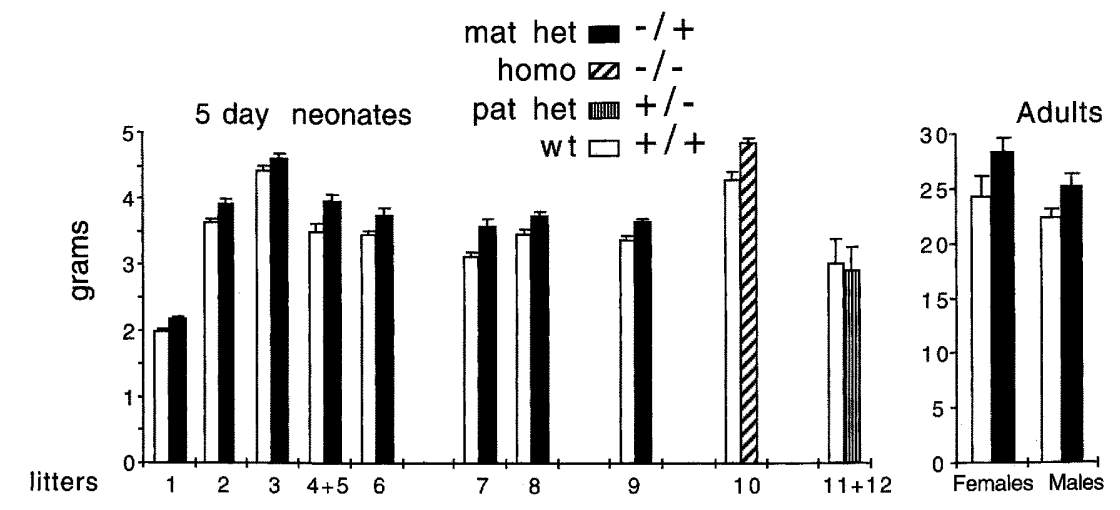

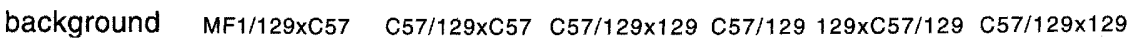

Figure 2. Growth of heterozygous and homozygous progeny carrying the H19 null mutation. Histograms represent the weight of heterozygous or homozygous vs. wild-type 5-day neonates and adults in individual litters from different backgrounds (see Table 1). served $4.2-\mathrm{kb}$ fragment results from the presence of a partially methylated HpaII site in the neo gene) and the 4-kb maternal fragment was sensitive to HpaII. Similar results were obtained with muscle DNA (data not shown). In conclusion, the paternal allele is methylated in both mat het and pat het animals, suggesting that the observed imprint of the paternal neo gene is correlated with allele-specific methylation of the $5^{\prime}$ upstream region.

\section{Expression of the Igf2 gene}

The $H 19$ gene is located at a distance of $80-\mathrm{kb}$ from the Igf2 gene. To analyze a possible interaction between these two genes, we performed a cross between $H 19$ heterozygous

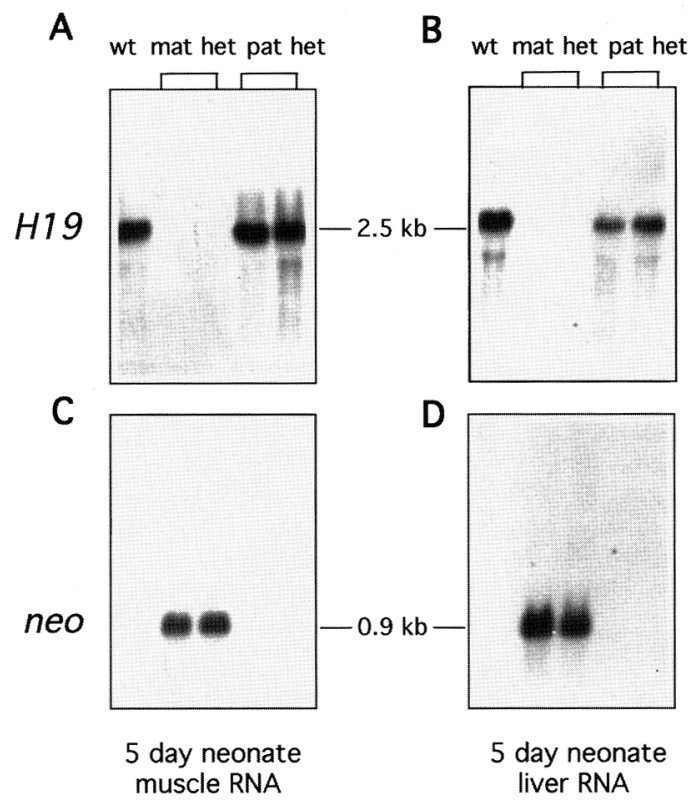

Figure 3. Expression of $H 19$ and neo genes in neonatal heterozygous mice. $(A, B)$ Northern analysis of 5-day neonate muscle $(A)$ and liver $(B)$ RNA with the $H 19$ probe. Genotypes of the mice are indicated at top; sizes of the transcripts are indicated in middle. $(C, D)$ Northern analysis of 5 -day neonate muscle $(C)$ and liver $(D)$ RNA. The same A and B filters were hybridized with the neo probe. females and Igf2 heterozygous males (kindly provided by A. Efstratiadis, Columbia University, New York, NY). These Igf2 heterozygous mice result from a targeted disruption of the Igf2 gene; it was shown that pat het animals, which do not express any Igf2, because Igf2 is expressed only from the paternal allele, show a $30 \%$ decrease in weight (DeChiara et al. 1990).

This cross gives rise to four genotypes corresponding to different epigenotypes as indicated in Figure 6A. The $\left[{\mathrm{H} 19^{+} / \text {Igf2 }}^{-}\right]$animals, having received a normal $\mathrm{H} 19$ allele from their mother and the Igf2 null mutation from their father, should display an Igf2 pat het phenotype. The $\left[{\mathrm{H} 19^{-}}^{-} / \mathrm{Igf2} \mathrm{C}^{+}\right]$animals, having received the $\mathrm{H} 19$ null mutation from their mother and a normal Igf2 allele from their father, should display an H19 mat het phenotype. The $\left[\mathrm{H19}^{-} / \mathrm{Igf2}^{-}\right]$double heterozygous animals should allow the analysis of Igf2 expression in the absence of $H 19$.

The progeny obtained were genotyped by digestion of tail DNA with EcoRI and Southern analysis using a neo probe. The $H 19$ targeted allele was revealed by a $5-\mathrm{kb}$ diagnostic fragment and the Igf2 targeted allele by an 11-kb diagnostic fragment (data not shown).

Analysis of the weight of 5 day neonates in each group showed the following results (Fig. $6 \mathrm{~B}$ ): $\left[\mathrm{H}_{19^{+}} /\right.$Igf2- $]$animals were $30 \%$ lighter than wild-type $\left[\mathrm{H} \mathrm{9}^{+} / \mathrm{Igf2} \mathrm{I}^{+}\right]$ones, as expected because these animals are Igf2 pat het. The $\left[\mathrm{H}^{1} \mathrm{9}^{-} / \mathrm{Igf2} \mathrm{2}^{-}\right]$animals were $7 \%$ lighter than their wildtype littermates $(P<0.1)$. The $\left[\mathrm{H} \mathrm{P}^{-} / \mathrm{Igf2} 2^{+}\right]$animals are not shown because of a low sample number in this particular cross; however, in other crosses, as shown in Table 1, H19 mat het animals were on average $8 \%$ heavier than wild-type animals.

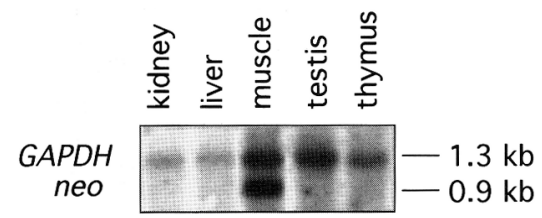

Figure 4. Northern analysis of adult tissues (6 months old) from a mat het animal. The neo probe was hybridized to RNA from the indicated tissues. A GAPDH probe was used as control. Sizes of the transcripts are indicated at right. 


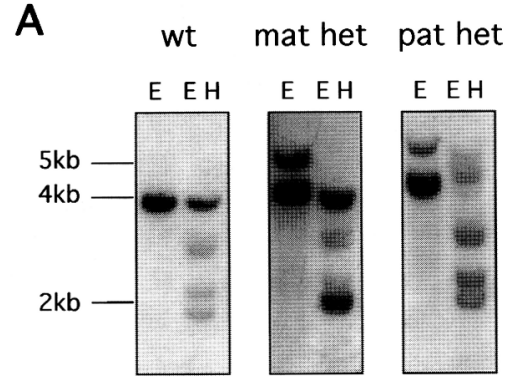

B

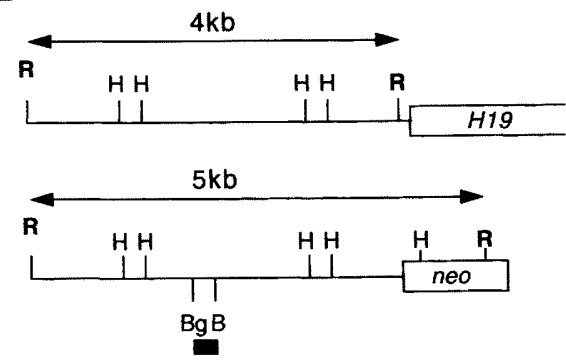

Figure 5. Analysis of DNA methylation of the $5^{\prime}$ upstream region of the $H 19$ gene. (A) Liver genomic DNAs from wildtype, mat het, and pat het 5-day neonates were digested with EcoRI (E) or with EcoRI and HpaII (EH) and separated on $1 \%$ agarose gels. The Southern blots were hybridized with the BgIII$B a m H I$ 200-bp probe shown in B. Molecular sizes are indicated on left. $(B)$ Restriction map of the $5^{\prime}$ region of H19. (Top) The wild-type 4-kb EcoRI fragment upstream from the $H 19$ gene. (Bottom) The 5-kb EcoRI fragment resulting from the replacement of $H 19$ by the neo cassette. The $B g I I I-B a m H I 200$-bp probe is indicated below. (R) EcoRI; (B) BamHI; (Bg) BglII; (H) HpaII.

To correlate these observations with the level of Igf2 transcription, Northern analysis was performed on muscle RNA from 5-day neonates (Fig. $6 \mathrm{C}$ ). $\left[{\mathrm{H} 19^{+}}^{+} / \mathrm{Igf2}^{-}\right]$ animals (Igf2 pat het) showed expression of $\mathrm{H} 19$ and no expression of Igf2 mRNA, as reported before (DeChiara et al. 1990). Unexpectedly, $\left[\mathrm{H}^{-1} \mathrm{9}^{-} / \mathrm{Igf2} \mathrm{2}^{-}\right]$animals, which carry only one Igf2 allele of maternal origin, expressed Igf2 transcripts. However, the level of Igf2 was only $25 \%$ compared with $100 \%$ in wild-type animals (Fig. 6D). $\left[\mathrm{H}^{1} \mathrm{9}^{-} / \mathrm{Igf2} \mathrm{2}^{+}\right]$animals (H19 mat het) displayed higher amounts of Igf2 transcripts (125\%) than wild-type animals and no $H 19$ transcript.

The maternal Igf2 allele, which is normally silent, is therefore expressed in the absence of the maternal H19 gene in cis. However, the maternal Igf2 level of expression is lower than the wild-type paternal Igf2 level. This correlates with the partial rescue of the Igf2 phenotype, as indicated by the $7 \%$ weight reduction of these animals compared with wild-type animals.

\section{Discussion}

The chromosomal regions subject to imprinting appear to contain clusters of genes displaying parental-specific differential expression. This has been shown not only for the distal region of mouse chromosome 7 , containing the H19-Igf2 locus, but also in a more central region of this chromosome containing the Snrpn gene, homologous to the Prader-Willi-Angelman syndrome locus on human chromosome 15 (Nicholls 1994). X chromosome inactivation is yet another example of long-range control, because the paternal $\mathrm{X}$ chromosome is preferentially inactivated in extraembryonic tissues and the Xist gene is

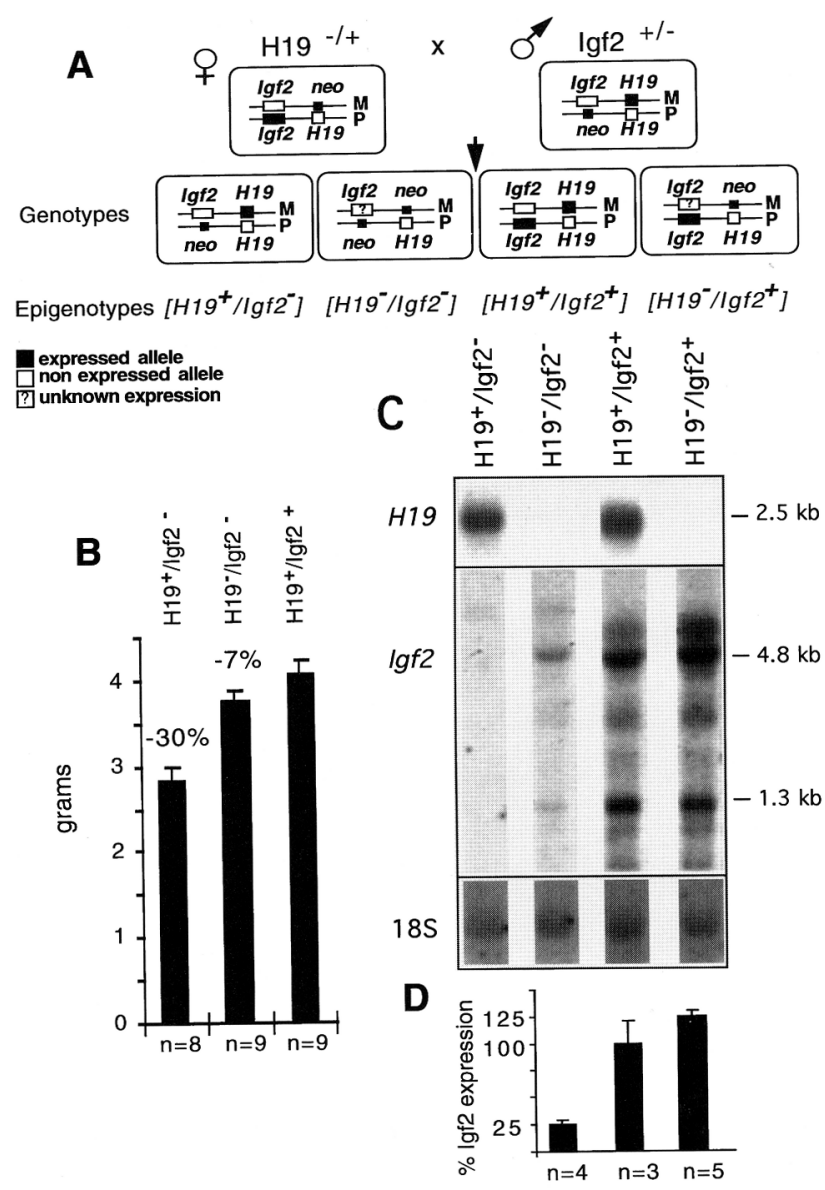

Figure 6. Analysis of the progeny from a cross between $H 19^{-/+}$ females and $\operatorname{lgf2^{+1-}}$ males. $|A|$ Schematic representation of expected progeny. Genotypes of the progeny are represented in the rectangles and abbreviated epigenotypes are indicated below. The Igf2 null allele was generated by replacing exon 1 by the neo cassette, whereas the entire $H 19$ gene is deleted in our animals. (M) Maternal allele; $(\mathrm{P})$ paternal allele. $(B)$ Weight analysis of the different epigenotypes. Histogram representing the weight of 5-day neonates from each epigenotype ( $\mathrm{n}$, number of animals). Percentage of decrease in weight compared with wild-type animals $\left[\mathrm{H}^{1} \mathrm{9}^{+} / \mathrm{Igf2} \mathrm{2}^{+}\right](100 \%)$ is shown at the top of each bar. $(\mathrm{C})$ Northern analysis of 5-day neonate muscle RNA from the four epigenotypes. The size of the $H 19$ transcript and of the two main Igf2 transcripts detected in muscle RNA is shown on the right. An $18 \mathrm{~S}$ oligonucleotide probe was used to estimate the levels of RNA in each sample. $(D)$ The corresponding histogram, obtained from the Northern analysis of several animals, represents the percentage of Igf2 transcripts for each epigenotype compared with wild-type level $(100 \%)$. (n) Number of RNA samples analyzed. 
imprinted (Kay et al. 1993, 1994). The imprinting mechanism must result from a complex gene regulation over large distances, involving chromatin structure, transacting factors, and cis-acting sequences. The targeted disruption of the $H 19$ gene has enabled the study of some aspects of the regulatory mechanism involved in imprinting.

We have generated null mutant animals in which only the $3-\mathrm{kb}$ transcription unit of the $H 19$ gene has been deleted. We will refer to this mutation as the $H 19^{\Delta 3}$ allele. Our results have shown that this loss of function mutation does not affect embryogenesis of the mouse: Although $\mathrm{H} 19$ is first detected in the trophectoderm cells of the blastocyst and is then expressed at high levels in endodermal and mesodermal tissues of the mid-gestation embryo, it does not appear to play a fundamental role in development. The null mutant mice are viable and fertile, and after one year of breeding, no other obvious phenotype has been detected apart from a weight increase of the maternal heterozygous and homozygous animals compared with wild-type littermates. This gene might be subject to redundancy and other genes might be accomplishing the same function. There is, however, no indication of a multigene family related to the $\mathrm{H} 19$ gene. It is also possible that the sheltered breeding conditions in which the mice are maintained do not allow the detection of a more severe phenotype in these mutant animals. Alternatively, it could be that this gene must be repressed in certain tissues to allow full development of the embryo. To address this question requires experiments involving ectopic expression of H19 in nonexpressing tissues of the embryo.

Several studies have revealed a modification of the imprint in embryonal human tumors related to the Beckwith-Wiedemann syndrome such as Wilm's tumors and rhabdomyosarcomas (Ohlsson et al. 1993; Moulton et al. 1994; Steenman et al. 1994; Reik et al. 1995; Taniguchi et al. 1995). In these tumors, expression of H19 is no longer detected and the adjacent Igf2 gene is frequently expressed biallelically. These observations could be related to the tumor suppressor role proposed for $\mathrm{H} 19$ (Hao et al. 1993). It is noteworthy that mutant animals lacking the $\mathrm{H} 19$ gene have not shown any incidence of tumors, although they are now over a year of age. The animal model that we have generated suggests that absence of $H 19$ expression is not sufficient to induce tumors in mice.

H19 expression is strongly down-regulated in adult mice and is found only in muscle tissues. Expression analysis of the neo cassette that has replaced the H19 transcription unit has shown that the only adult tissue of mutant mice in which the neo transcripts are detected is muscle. Regulatory elements involved in the correct spatio-temporal expression of the $\mathrm{H} 19$ locus have thus been maintained in these mutant animals. Interestingly, this suggests that these regulatory elements can override the tissue-specificity of the $P y$ enhancer, because one of the target organs for polyoma virus is the kidney (Dawe et al. 1987; Rochford et al. 1990).

One striking observation is the imprint of the neo cas- sette in heterozygous animals. The neo gene is expressed only when inherited from the maternal allele in neonatal muscle and liver, and no expression is detected in pat het animals, which carry the neo cassette on the paternal allele. Signals responsible for inducing a closed chromatin configuration on the paternal allele must have been maintained in the $\mathrm{H}_{19^{43}}$ mutation, such that the neo cassette that has replaced the $H 19$ transcription unit is imprinted. A similar regulation was described previously for an X-linked neo transgene that was subject to correct imprinting and X inactivation (Dandolo et al. 1993) and for the neo cassette introduced in the Igf2 mutation (DeChiara et al. 1991). Recent transgene experiments have suggested that the structural $H 19$ gene or the $H 19$ RNA itself may be involved in its own imprint (Pfeifer et al. 1996; Elson and Bartolomei 1997). Our present study, however, clearly shows that in the context of the chromatin structure of chromosome 7, neither the H19 DNA sequence nor transcription of the $\mathrm{H} 19$ gene itself is required for establishment or maintenance of imprinting at this locus.

In addition, our results are in contrast with the targeted disruption of $H 19$ described previously (Leighton et al. 1995a), in which biallelic expression of neo was observed. In these animals, a 13-kb deletion encompassing not only $H 19$ but also $10-\mathrm{kb}$ of the $5^{\prime}$ upstream region of the transcription unit had been generated. We propose to refer to this latter mutation as the $H 19^{\Delta 13}$ allele. Taken together, these results show that the $10-\mathrm{kb}$ sequence located $5^{\prime}$ to the $H 19$ gene is required for the imprint at the $H 19$ locus (Fig. 7). This suggests that the H19 5' upstream region contains an imprinting control element. This $5^{\prime}$ region has been shown to display allelespecific methylation correlated with differential expression of $H 19$ and to include several repeats of a (G)GGGGTATA consensus sequence (Bartolomei et al. 1993; Ferguson-Smith et al. 1993; Tremblay et al. 1995). Analysis of DNA methylation of this region in the $H 19^{\Delta 3}$ mutants showed that only the paternal allele is methylated. Allele-specific methylation has thus been maintained in the mutant animals.

Among known imprinted genes, three have been identified that encode a possible functional RNA: H19, IPW (Wevrick et al. 1994), and Xist. It has been shown that the Xist gene, exclusively expressed from the inactive $\mathrm{X}$ chromosome, is involved in the inactivation of adjacent genes (Clemson et al. 1996; Lee et al. 1996; Penny et al. 1996; Herzing et al. 1997; Lee and Jaenisch 1997). One could suggest a possible similarity in the role of these genes, being involved in the down-regulation of expression of chromosomal domains, and acting through a cis effect of their RNA: Xist on genes of the inactive X chromosome and H19 on the Igf2-Ins2 region. The H19 RNA itself may thus regulate the silencing of the $I g f 2$ gene by a cis effect. A possible example of this effect is the presence of biallelic Igf2 expression in the absence of $H 19$ expression in certain human tumors (as mentioned abovel.

The results obtained from the cross between $H 19^{\Delta 3}$ and Igf2 heterozygous mutant animals have shown that 
Figure 7. Schematic representation of the H19Igf2 locus in $H 19^{w t}, H 19^{\Delta 3}$, and $H 19^{\Delta 13}$ animals. Only maternal alleles of each animal are shown in the diagram. The arrows show the direction of transcription. The EcoRI fragment $(-10 \mathrm{~kb}$ to -50 bp) containing the putative imprinting control element is shown below by a bold line. The endoderm enhancers $\langle\mathrm{E}\rangle$ at +9 and $+11 \mathrm{~kb}$ are shown by circles. (R) EcoRI; (S) SalI. H19 ${ }^{\Delta 3}$ animals display imprinted expression of the neo gene, whereas $H 19^{\Delta 13}$ animals display biallelic expression of this gene.
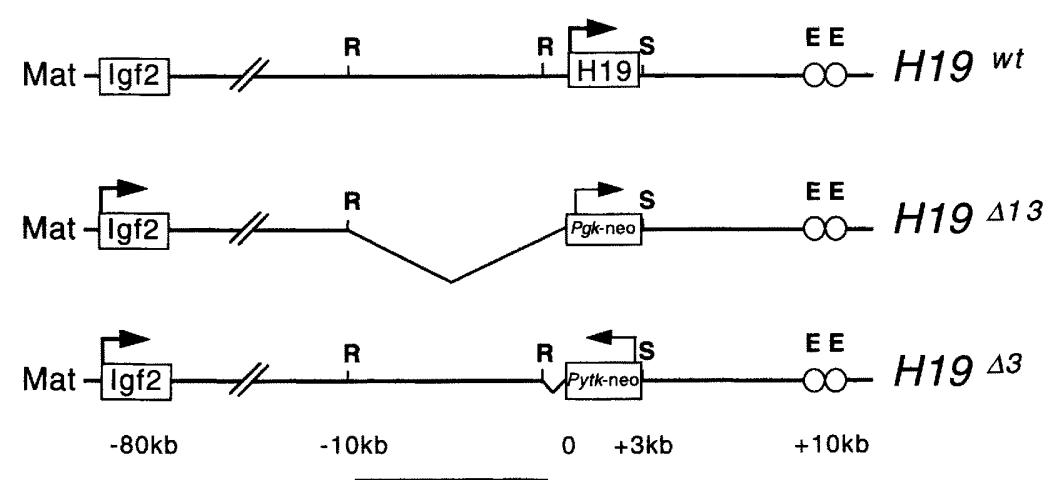

a regulatory link can be established between these two genes. Absence of a maternally expressed $H 19$ gene is associated with expression of the normally silent adjacent Igf2 gene on the same chromosome. This loss of imprint of Igf2 resulting in its biallelic expression is correlated with the observed weight increase of the H19 mutant animals. Disruption of Igf2 imprint has now been observed in two cases (Fig. 7): (1) In these $H 19^{\Delta 3}$ mutants, the level of maternal Igf2 expression corresponds to $25 \%$ of the paternal level and is correlated with an $8 \%$ weight increase and only partial rescue of the Igf2 weight phenotype in $H 19^{\Delta 3}$-Igf2 double heterozygous mutant animals; (2) in the $H 19^{\Delta 13}$ mutant animals described by Leighton et al. (1995a), the level of expression of maternal Igf2 is similar to paternal Igf2 in muscle and is correlated with a $27 \%$ weight increase and with total rescue of the Igf2 mutant phenotype in double $H 19^{\Delta 13}-I g f 2$ heterozygous mutant animals. Because the $H 19^{\Delta 3}$ deletion of the transcription unit leads to only limited loss of imprint, it appears that Igf2 transcription is not controlled exclusively by cis expression of the H19 gene. Taken together with the results described for the $H 19^{\Delta 13}$ mutation, this suggests that the region $10 \mathrm{~kb}$ upstream of $\mathrm{H} 19$ itself is also involved in controlling Igf2 expression and that the $H 19$ region is a complex structure that contains at least two elements involved in the control of adjacent genes: One is the H19 gene itself and the other is the 5' upstream region of the gene.

It must be taken into account, however, that the difference between the phenotypic consequences of these two mutations could also reflect differences in the constructs used for targeting. First, the two deletions could result in disruption of the chromatin structure of the region, thus leading to different levels of maternal Igf2 transcription. Second, it has been suggested that $H 19$ and Igf2 compete for a common enhancer (Leighton et al. 1995b). Because the $H 19$ upstream sequences have been deleted in both $H 19^{\Delta 3}$ and $H 19^{\Delta 13}$ mutations, the enhancer may now interact with the Igf2 promoter on the maternal allele. However, it may also interact with the replacement genes, and the relative strength of the $P y-t k$ (in the $H 19^{\Delta 3}$ mutation) and $P g k$ (in the $H 19^{\Delta 13}$ mutation) promoters of the neo cassettes could account for the observed different levels of maternal Igf2 expression (Fig. 7).
In conclusion, the $H 19^{\Delta 3}$ null mutation of the $H 19$ gene has shown that this gene is dispensable during embryonic development and leads to a phenotype of larger animals as a result of biallelic expression of the adjacent Igf2 gene. Absence of the $H 19$ transcription unit modifies the imprint of the Igf2 gene. The replacement neo cassette shows the same pattern of parental imprinting and tissue-specific expression as H19. Taken together with the $H 19^{\Delta 13}$ mutants reported previously, our results suggest that the region $10 \mathrm{~kb}$ upstream of $H 19$ carries a putative imprinting control element. Further experiments using subtle mutations in this upstream region or in the RNA sequence itself of the $H 19$ gene should allow a more precise definition of the regulatory events involved in the control of this imprinted region.

\section{Materials and methods}

Disruption of the $\mathrm{H} 19$ gene.

An $H 19$ genomic clone was isolated from a $129 \lambda$ FixII mouse genomic library (Stratagene) and the phage insert was subcloned into pBluescript KSII. The targeting vector carries a deletion of the EcoRI-SalI fragment encompassing the $H 19$ transcription unit and $50 \mathrm{bp}$ of the promoter (Fig. 1B). It is composed from left to right of pBluescript, a 2-kb BamHI-EcoRI fragment from the 5 ' end of the gene $(-2$ to $-50 \mathrm{bp}$ ), the pMC1-neo cassette (Stratagene) inserted in opposite orientation, a $6.5-\mathrm{kb}$ Sall-BgIII fragment from the $3^{\prime}$ end of the gene (from +3 to $+9.5 \mathrm{~kb}$ ) and the pMC1-tk cassette. The vector was linearized at a unique NotI site and electroporated into embryonic stem (CK35 ES) cells.

The CK35 ES cell line was established according to procedures described previously using blastocysts from superovulated 129 female mice (Robertson 1987). These cells are maintained on neo ${ }^{\mathrm{r}}$ mouse embryo fibroblasts in the presence of leukemia inhibitory factor (LIF) $\left(10^{3} \mathrm{U} / \mathrm{ml}\right)$. They were tested for efficiency of chimerism and germ-line transmission after microinjection into $\mathrm{C} 57 \mathrm{BL} / 6$ blastocysts prior to transfection procedures.

Embryonic stem (ES) cells $\left(2 \times 10^{7}\right)$ in $0.5 \mathrm{ml}$ were electroporated with $15 \mu \mathrm{g}$ of DNA using a Bio-Rad Gene Pulser apparatus at $220 \mathrm{~V}$ and $960 \mu \mathrm{F}$ in PBS or medium. G418 selection $(200$ $\mu \mathrm{g} / \mathrm{ml}$ effective concentration) (GIBCO) was applied $48 \mathrm{hr}$ later and gancyclovir $\left(2 \times 10^{-6} \mathrm{M}\right)$ (Syntex) was added on day 4 or 5 after electroporation. This double selection provided a 5 -fold enrichment in positive clones compared with G418 selection alone. These clones were picked after 8-10 days and grown in 96-well plates. They were then divided into two 24 -well plates, 
one being frozen directly in serum with $10 \%$ DMSO when confluent and the other being kept for DNA extraction.

Genomic DNA from individual clones was prepared, digested with EcoRI, separated on $1 \%$ agarose gels, blotted to Hybond $\mathrm{N}^{+}$ (Amersham) filters, and hybridized to ${ }^{32} \mathrm{P}$-labeled random primed probes (Sambrook et al. 1989). Hybridization was performed in Church buffer at $65^{\circ} \mathrm{C}$ overnight (Church and Gilbert 1984). Blots were washed in $0.4 \times \mathrm{SSC}, 0.5 \% \mathrm{SDS}$ for $30 \mathrm{~min}$ at $65^{\circ} \mathrm{C}$.

The $5^{\prime}$ external probe is a $B g I I I-B a m H I$ 200-bp fragment at -2 $\mathrm{kb}$ and the $3^{\prime}$ external probe is a BgIII-EcoRI $1-\mathrm{kb}$ fragment from +9.5 to $+10.5 \mathrm{~kb}$ (Fig. 1B). The neo probe is a $1.1-\mathrm{kb}$ XhoI-BamHI fragment from the $\mathrm{pMC1}$-neo plasmid.

\section{Blastocyst injections and mating of chimeric mice}

One of the correctly targeted clones (cl 19) was injected into MF1 or C57BL/ 6 blastocysts. Germ-line transmission was very low with MF1-derived chimeric males $(0.5 \%-3 \%)$ and much higher with C57BL/6-derived chimeras $(25 \%-100 \%)$. Heterozygous and homozygous animals were obtained from these different crosses.

\section{Rapid testing for heterozygotes}

Heterozygous animals were analyzed by a rapid PCR procedure. Tail samples were digested in $200 \mu 1$ of lysis buffer $(50 \mathrm{~mm} \mathrm{KCl}$, $10 \mathrm{~mm}$ Tris at $\mathrm{pH} 8.3,2.5 \mathrm{~mm} \mathrm{MgCl}_{2}, 4.5 \% \mathrm{NP}_{40}, 4.5 \%$ Tween $20,1 \mathrm{mg} / \mathrm{ml}$ of proteinase $\mathrm{K})$. A 35-cycle PCR reaction $\left(94^{\circ} \mathrm{C}\right.$ for $1 \mathrm{~min}, 55^{\circ} \mathrm{C}$ for $30 \mathrm{sec}, 72^{\circ} \mathrm{C}$ for $30 \mathrm{sec}$ using neo-specific oligonucleotides (Dandolo et al. 1993) was directly performed on $2.5 \mu \mathrm{l}$ of DNA after a preliminary incubation at $95^{\circ} \mathrm{C}$ for $10 \mathrm{~min}$ before adding Taq polymerase (Hanley and Merlie 1991).

\section{Northern blot analysis}

RNA was extracted from 5-day neonatal or adult tissues using RNAXEL (Eurobio). For Northern analysis, $20 \mu \mathrm{g}$ of total RNA was denatured at $68^{\circ} \mathrm{C}$ for $10 \mathrm{~min}$ in $50 \%$ formamide, $2.2 \mathrm{M}$ formaldehyde, $5 \mathrm{~mm}$ sodium acetate, $1 \mathrm{~mm}$ EDTA, $20 \mathrm{~mm}$ MOPS at $\mathrm{pH} 7.0$ and separated in a $1 \%$ agarose, $2.2 \mathrm{M}$ formaldehyde gel in MOPS buffer (Sambrook et al. 1989). The RNAs were transferred to Hybond $\mathrm{N}^{+}$filters in $10 \times$ SSC. Hybridizations were performed in Church buffer and filters were washed in $0.4 \times \mathrm{SSC}, 0.5 \%$ SDS at $60^{\circ} \mathrm{C}$ (cDNA probes) or $42^{\circ} \mathrm{C}$ (oligonucleotide probe). Ethidium bromide staining, 18S, or Gapdh probes were used as loading controls. Quantification of Northerns was performed using Image master (Pharmacia).

Igf2 transcripts were detected with a rat Igf2 cDNA probe (Soares et al. 1985) and H19 and Gapdh transcripts were detected with mouse (Fort et al. 1985) and rat (Poirier et al. 1991) cDNA probes, respectively. The $18 \mathrm{~S}$ probe was an oligonucleotide probe: 5'-AGACGACCGCTCGGGGGTCGCG-3' .

\section{DNA methylation analysis}

Liver genomic DNAs from heterozygous (mat het and pat het) and wild-type 5-day neonate animals were digested with EcoRI or with EcoRI and HpaII. DNA samples $(20 \mu \mathrm{g})$ were separated on $1 \%$ agarose gels, transferred to Hybond $\mathrm{N}^{+}$, and hybridized to the $B g I I I-B a m H I$ 200-bp probe as described above.

\section{Acknowledgments}

We thank A. Efstratiadis for kindly providing the $I g f 2^{-}$mice; $\mathrm{N}$. Bazin and J.J. Puyol for their help with the mouse breeding; $\mathrm{E}$. Campion, K. Mesbah, and X. Montagutelli for help with the statistical analysis; and E. Heard, C. Babinet, D. Blangy, A. Paldi, and J. Jami for helpful discussions and critical reading of the manuscript. This work was supported by grants from the Association Française contre les Myopathies and the Association de Recherche sur le Cancer.

The publication costs of this article were defrayed in part by payment of page charges. This article must therefore be hereby marked "advertisement" in accordance with 18 USC section 1734 solely to indicate this fact.

\section{References}

Barlow, D.P. 1995. Gametic imprinting in mammals. Science 270: $1610-1613$.

Bartolomei, M.S., S. Zemel, and S.M. Tilghman. 1991. Parental imprinting of the mouse H19 gene. Nature 351: 153-155.

Bartolomei, M.S., A.L. Webber, M.E. Brunkow, and S.M. Tilghman. 1993. Epigenetic mechanisms underlying the imprinting of the mouse H19 gene. Genes \& Dev. 7: 1663-1673.

Beechey, C.V. and B.M. Cattanach. 1996, Genetic imprinting map. Mouse Genome 94: 96-99.

Brannan, C.I., E.C. Dees, R.S. Ingram, and S.M. Tilghman. 1990. The product of the $\mathrm{H} 19$ gene may function as an RNA. Mol Cell. Biol. 10: 28-36.

Cattanach, B.M. and M. Kirk. 1985. Differential activity of maternally and paternally derived chromosome regions in mice. Nature 315: 496-498.

Church, G.M. and W. Gilbert. 1984. Genomic sequencing. Proc. Nat1. Acad. Sci. 81: 1991-1995.

Clemson, C.M., J.A. McNeil, H. Willard and J.B. Lawrence. 1996. XIST RNA paints the inactive X chromosome at interphase: Evidence for a novel RNA involved in nuclear/ chromosome structure. I. Cell Biol. 132: 1-17.

Dandolo, L., C. Stewart, M.G. Mattei, and P. Avner. 1993. Inactivation of an X-linked transgene in murine extraembryonic and adult tissues. Development 118: 641-649.

Dawe, C.J., R. Freund, G. Mandel, K.B. Hofer, D.A. Talmage, and T.L. Benjamin. 1987. Variations in polyoma virus genotype in relation to tumor induction in mice. Am. J. Pathol. 127: 243-261.

DeChiara, T.M., A. Efstratiadis, and E.J. Robertson. 1990. A growth deficiency phenotype in heterozygous mice carrying an insulin-like growth factor II gene disrupted by gene targeting. Nature 345: 78-80.

DeChiara, T.M., E.J. Robertson, and A. Efstratiadis. 1991. Parental imprinting of the mouse insulin-like growth factor II gene. Cell 64: 849-859.

Deltour, L., X. Montagutelli, J.L. Guenet, J. Jami, and A. Paldi. 1995. Tissue- and developmental stage-specific imprinting of the mouse proinsulin gene, Ins2. Dev. Biol. 168: 686-688.

Elson, D.A. and M.S. Bartolomei. 1997. A $5^{\prime}$ differentially methylated sequence and the $3^{\prime}$-flanking region are necessary for H19 transgene imprinting. Mol. Cell. Biol. 17: 309-317.

Ferguson-Smith, A.C., H. Sasaki, B.M. Cattanach, and M.A. Surani. 1993. Parental-origin-specific epigenetic modifications of the mouse $H 19$ gene. Nature 362: 751-755.

Fort, P., L. Marty, M. Piechaczyk, S.E. Sabrouty, C. Dani, P. Jeanteur, and J.M. Blanchard. 1985. Various rat adult tissues express only one major mRNA species from the glyceraldehyde-3-phosphate-dehydrogenase family. Nucleic Acids Res. 13: $1431-1442$. 
Giannoukakis, N., C. Deal, J. Paquette, C.G. Goodyer, and C. Polychronakos. 1993. Parental genomic imprinting of the human IGF2 gene. Nature Genet. 4: 98-101.

Giddings, S.J., C.D. King, K.W. Harman, J.F. Flood, and L.R. Carnaghi. 1994. Allele specific inactivation of insulin 1 and 2 , in the mouse yolk sac, indicates imprinting. Nature Genet. 6: 310-313.

Guillemot, F., T. Caspary, S.M. Tilghman, N.G. Copeland, D.J. Gilbert, N.A. Jenkins, D.J. Anderson, A.L. Joyner, J. Rossant, and A. Nagy. 1995. Genomic imprinting of Mash2, a mouse gene required for trophoblast development. Nature Genet 9: $235-242$.

Hanley, T. and J.P. Merlie. 1991. Transgene detection in unpurified mouse tail DNA by polymerase chain reaction. BioTechniques 10: 56 .

Hao, Y., T. Crenshaw, T. Moulton, E. Newcomb, and B. Tycko. 1993. Tumour-suppressor activity of H19 RNA. Nature 365: 764-767.

Hatada, I. and T. Mukai. 1995. Genomic imprinting of p57KIP2, a cyclin-dependent kinase inhibitor, in mouse. Nature Genet. 11: 204-206.

Herzing, L.B.K., J.T. Romer, J.M. Horn, and A. Ashworth. 1997. Xist has properties of the X-chromosome inactivation center. Nature 386: 272-275.

John, R.M. and M.A. Surani. 1996. Imprinted genes and regulation of gene expression by epigenetic inheritance. Curr. Opin. Cell Biol. 8: 348-353.

Kay, G.F., G.D. Penny, D. Patel, A. Ashworth, N. Brockdorff, and S. Rastan. 1993. Expression of Xist during mouse development suggests a role in the initiation of $\mathrm{X}$ chromosome inactivation. Cell 72: 171-182.

Kay, G.F., S.C. Barton, M.A. Surani, and S. Rastan. 1994. Imprinting and $\mathrm{X}$ chromosome counting mechanisms determine Xist expression in early mouse development. Cell 77: 639-650.

Lee, J.T. and R. Jaenisch. 1997. Long-range cis effects of ectopic $\mathrm{X}$-inactivation centres on a mouse autosome. Nature 386: 275-279.

Lee, J.T., W.M. Strauss, J.A. Dausman, and R. Jaenisch. 1996. A $450 \mathrm{~kb}$ transgene displays properties of the mammalian $\mathrm{X}$ inactivation center. Cell 86: 83-94.

Leighton, P.A., R.S. Ingram, J. Eggenschwiler, A. Efstratiadis, and S.M. Tilghman. 1995a. Disruption of imprinting caused by deletion of the $\mathrm{H} 19$ gene region in mice. Nature 375: 3439.

Leighton, P.A., J.R. Saam, R.S. Ingram, C.L. Stewart, and S.M. Tilghman. 1995b. An enhancer deletion affects both H19 and Igf2 expression. Genes \& Dev. 9: 2079-2089.

Li, E., C. Beard, and R. Jaenisch. 1993. Role for DNA methylation in genomic imprinting. Nature 366: 362-365.

Matsuoka, S., J.S. Thompson, M.C. Edwards, J.M. Bartletta, P. Grundy, L.M. Kalikin, J.W. Harper, S.J. Elledge, and A.P. Feinberg. 1996. Imprinting of the gene encoding a human cyclin-dependent kinase inhibitor, p57KIP2, on chromosome 11p15. Proc. Natl. Acad. Sci. 93: 3026-3030.

McGrath, J. and D. Solter. 1984. Completion of embryogenesis requires both the maternal and paternal genomes. Cell 37: $179-183$

Moulton, T., T. Crenshaw, Y. Hao, J. Moosikasuwan, N. Lin, F. Dembitzer, T. Hensle, L. Weiss, L. McMorrow, T. Loew, et al. 1994. Epigenetic lesions at the H19 locus in Wilms' tumour patients. Nature Genet. 7: 440-447.

Nicholls, R.D. 1994. New insights reveal complex mechanisms involved in genomic imprinting. Am. I. Hum. Genet. 54: 733-740

Ohlsson, R., A. Nyström, S. Pfeifer-Ohlsson, V. Töhönen, F.
Hedborg, P. Schofield, F. Flam, and T.J. Ekström. 1993. IGF2 is parentally imprinted during human embryogenesis and in the Beckwith-Wiedemann syndrome. Nature Genet. 4: 94 97.

Pachnis, V., C.I. Brannan, and S.M. Tilghman. 1988. The structure and expression of a novel gene activated in early mouse embryogenesis. EMBO I. 7: 673-681.

Penny, G.D., G.F. Kay, S.A. Sheardown, S. Rastan, and N. Brockdorff. 1996. Requirement for Xist in X chromosome inactivation. Nature 379: 131-137.

Pfeifer, K., P.A. Leighton, and S.M. Tilghman. 1996. The structural $\mathrm{H} 19$ gene is required for transgene imprinting. Proc. Nat1. Acad. Sci. 93: 13876-13883.

Poirier, F., C.-T.J. Chan, P.M. Timmons, E.J. Robertson, M.J. Evans, and P.W.J. Rigby. 1991. The murine $\mathrm{H} 19$ gene is activated during embryonic stem cell differentiation in vitro and at the time of implantation in the developing embryo. Development 113: 1105-1114.

Razin, A. and H. Cedar. 1994. DNA methylation and genomic imprinting. Cell 77: 473-476.

Reik, W., K.W. Brown, H. Schneid, Y. Lebouc, W. Bickmore, and E.R. Maher. 1995. Imprinting mutations in the BeckwithWiedemann syndrome suggested by an altered imprinting pattern in the IGF2-H19 domain. Hum. Mol. Genet. 4: 2379-2385.

Robertson, E.J. 1987. Embryo-derived stem cell lines. In Teratocarcinomas and embryonic stem cells: A practical approach (ed. E.J. Robertson), pp. 71-112. IRL Press, Oxford, UK.

Rochford, R., B.A. Campbell, and L.P. Villarreal. 1990. Genetic analysis of the enhancer requirements for polyomavirus DNA replication in mice. J. Virol. 64: 476-485.

Sambrook, J., T. Maniatis, and E.F. Fritsch. 1989. Molecular cloning: A laboratory manual. Cold Spring Harbor Laboratory Press, Cold Spring Harbor, NY.

Sasaki, H., A.C. Ferguson-Smith, A.S.W. Shum, S.C. Barton, and M.A. Surani. 1995. Temporal and spatial regulation of H19 imprinting in normal and uniparental mouse embryos. Development 121: 4195-4202.

Soares, M.B., D.N. Ishii, and A. Efstratiadis. 1985. Developmental and tissue-specific expression of a family of transcripts related to rat insulin-like growth factor II RNA. Nucleic Acids Res. 13: 1119-1134.

Steenman, M.J., S. Rainier, C.J. Dobry, P. Grundy, I.L. Horon, and A.P. Feinberg. 1994. Loss of imprinting of IGF2 is linked to reduced expression and abnormal methylation of $\mathrm{H} 19$ in Wilms' tumour. Nature Genet. 7: 433-439.

Surani, M.A., S. Barton, and M. Norris. 1984. Development of reconstituted mouse eggs suggests imprinting of the genome during gametogenesis. Nature 308: 548-550.

Taniguchi, T., M.J. Sullivan, O. Ogawa, and A.E. Reeve. 1995. Epigenetic changes encompassing the IGF2/H19 locus associated with relaxation of IGF2 imprinting and silencing of H19 in Wilms tumor. Proc. Natl. Acad. Sci. 92: 2159-2163.

Tremblay, K.D., J.R. Saam, R.S. Ingram, S.M. Tilghman, and M.S. Bartolomei. 1995. A paternal-specific methylation imprint marks the alleles of the mouse $\mathrm{H} 19$ gene. Nature Genet. 9: 407-413.

Wevrick, R., J.A. Kerns, and U. Francke. 1994. Identification of a novel paternally expressed gene in the Prader-Willi syndrome region. Hum. Mol. Genet. 3: 1877-1882.

Zemel, S., M. Bartolomei, and S. Tilghman. 1992. Physical linkage of two mammalian imprinted genes, H19 and insulinlike growth factor 2. Nature Genet. 2: 61-65.

Zhang, Y. and B. Tycko. 1992. Monoallelic expression of the human $H 19$ gene. Nature Genet. 1: 40-44. 


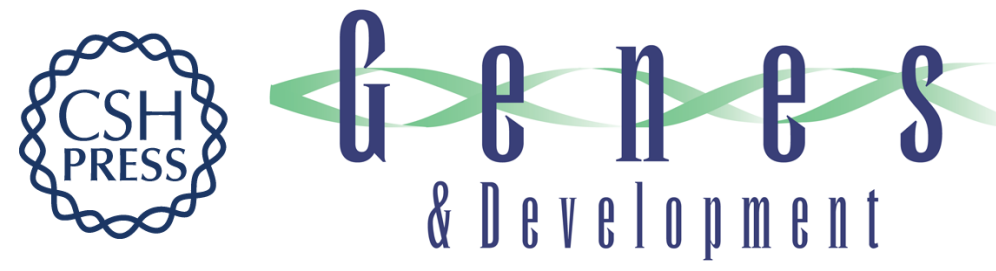

\section{Deletion of the $\mathrm{H} 19$ transcription unit reveals the existence of a putative imprinting control element.}

M A Ripoche, C Kress, F Poirier, et al.

Genes Dev. 1997, 11:

Access the most recent version at doi:10.1101/gad.11.12.1596

References This article cites 52 articles, 14 of which can be accessed free at:

http://genesdev.cshlp.org/content/11/12/1596.full.html\#ref-list-1

License

Email Alerting

Service

Receive free email alerts when new articles cite this article - sign up in the box at the top right corner of the article or click here.

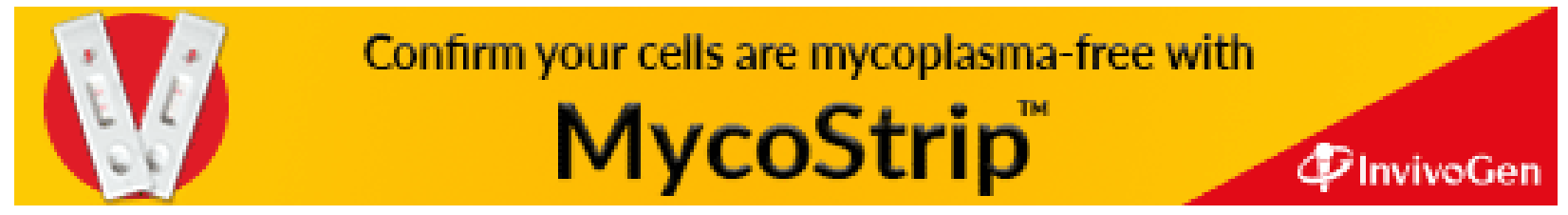

